\title{
NEOMITOLOGÍAS: LA ESTRATEGIA DEL MITO
}

Raúl Eguizábal ${ }^{1}$

Universidad Complutense de Madrid

r.eguizabal@ccinf.ucm.es

Material original autorizado para su primera publicación en la revista académica REDMARKA. Revista Digital de Marketing Aplicado.

https://doi.org/10.17979/redma.2012.01.09.4751

Recibido: 15 Octubre 2012

Aceptado: 13 Diciembre 2012

\section{Resumen}

El objetivo del estudio de los mitos es el de la compresión de la cultura, y la publicidad es uno de los ingredientes fundamentales de nuestra cultura. El objetivo de este artículo es el de intentar explicar los mecanismos de funcionamiento de la publicidad a través de su consideración como una modalidad de mito o mejor como una fábrica de mitos contemporáneos. Nuestro objetivo parte de una hipótesis: la publicidad es creadora de mitos. En la primera parte realizamos una serie de operaciones científicas clásicas que nos ayudarán a centrar el problema: definir, clasificar, teorizar. En la segunda. Nuestro discurso se moverá, dentro del paradigma del significado, en el terreno de la semiología, la iconología, la antropología y el análisis estructural del relato.

${ }^{1}$ RAÚl EGUIZÁBAL MAZA (Logroño, 1955) es profesor de Historia de la Publicidad en la Facultad de Ciencias de la Información. Catedrático de la Universidad Complutense y autor, entre otros, de los libros Historia de la Publicidad (Eresma, 1998: nueva edición Fragua, 2011); Fotografía publicitaria (Cátedra, 2001), Teoría de la publicidad (Cátedra, 2007); Industrias de la conciencia. Una historia social de la publicidad en España (Península, 2009); El estado del malestar: capitalismo tecnológico y poder sentimental (Península, 2011). Así como de numerosos artículos y capítulos de libro, entre los que se pueden citar: "Los orígenes del consumo moderno" (2005); "De la publicidad como actividad de producción simbólica" (2007); "Nuevas formas de expresión: diseño y publicidad (2009); "La historia del cartel como forma de historia cultural” (2010); "Publicidad y capitalismo tecnológico" (2011). 
Como conclusión, se establece que la publicidad puede ser explicada en términos de mitos; es eficaz en la medida en que emplea unos recursos (los mecanismos del mito) que han servido, desde los albores de la civilización, para ajustar el comportamiento de los ciudadanos a una situación, a un estado de cosas que, en nuestro caso, es el de una civilización del consumo. La forma de perpetuarse que tiene esa civilización es recurriendo a una serie de relatos míticos que llamamos anuncios o publicidad, por el cual existe un mundo "mejor" (un paraíso burgués) que se pone a nuestro alcance a través de las mercancías.

Palabras clave: Mitos, Publicidad, Marcas.

\section{Abstract}

NEW MYTHOLOGIES: THE STRATEGY OF MYTH

The objective of the study of myths is the compression of the culture, and advertising is one of the essential ingredients of our culture. The aim of this article is the attempt to explain the mechanisms of functioning of advertising through its consideration as a form of myth or better as a factory of contemporary myths. Our target part of a hypothesis: the advertising is creator of myths. In the first part, carry out a series of classic scientific operations that help us to focus the problem: define, classify, theorize. In the second our discourse will move within the paradigm of the meaning, in the field of semiology, the iconology, anthropology and the structural analysis of the story.

In conclusion, laying down that advertising can be explained in terms of myths; It is effective in that it uses resources (mechanisms of the myth) who have served since the dawn of civilization, to fit the behavior from the citizens to a situation, to a state of things that, in our case, is the one of a civilization of the consumption. The form to be perpetuated that it has that civilization, is by means of the resource to a series of mythical stories that we called announcements or advertising, by which exists "a better" world (a bourgeois paradise) that is put to our reach through the merchandise.

Key words: Myths. Advertising. Marks 


\section{Resumo}

O objetivo do estudo dos mitos é a compressão da cultura, e a publicidade é um dos ingredientes essenciais da nossa cultura. O objetivo deste artigo é a tentativa de explicar os mecanismos de funcionamento da publicidade através de sua consideração como uma forma de mito, ou melhor, como uma fábrica de Mitos contemporâneos. Nossa parte de destino de uma hipótese: a publicidade é criador de mitos. Na primeira parte, realizar uma série de operações científicas clássicas que nos ajudam a concentrar o problema: definir, classificar, teorizar. No segundo, nosso discurso moverá dentro do paradigma do significado, no campo da semiologia, a iconografia, Antropologia e análise estrutural da história. Em conclusão, que estabelece que a publicidade pode ser explicada em termos de mitos; É eficaz em que ele usa recursos (mecanismos do mito) que serviram desde os primórdios da civilização, para ajustar o comportamento dos cidadãos a uma situação, um estado de coisas que, no nosso caso, é de uma civilização de consumo. Como perpetuar o que que a civilização, é através do uso de uma série de histórias míticas que chamamos de anúncios ou publicidade, para o qual há um mundo "melhor" (um paraíso burguês) que coloca à nossa disposição dos bens.

Palavras chave: Mitos, publicidade, Marcas 


\section{INTRODUCCIÓN}

El estudio científico del mito se remonta a 1825, año de la publicación del estudio de Karl Otfried Müller Introducción a la mitología científica. A partir de esa fecha se inició una corriente de interés por el conocimiento de la mitología y sobre todo por la desmitificación; es decir, el análisis del mito se entendía más bien como un proceso desmitificador, hasta el punto de que en ese siglo, dominado por el positivismo, se estableció la idea, todavía muy extendida, de "mito" como un término opuesto a "realidad". Desde entonces, y a lo largo del siglo pasado, se multiplicaron los estudios sobre mitología (Frazer, Eliade, Kirk, Eliot, Campbell, Graves) desde diferentes perspectivas, fundamentalmente la antropología cultural, pero también la historia del arte, la filología, la historia cultural, el psicoanálisis, la filosofía, la semiología y otros.

Aunque el término griego mythos significaba originalmente "fábula" o "narración" o simplemente "habla", pasó así a oponerse a "logos" y a "historia". Sin embargo, aún admitiendo el mito como una forma de ficción (una creación humana, por tanto) difícilmente podríamos estar de acuerdo hoy con una concepción que se opone al conocimiento o a la historia o a la realidad.

El mito forma parte de una forma de conocimiento: el conocimiento mítico, bien diferente al conocimiento científico, es cierto, pero con unos mismos fines: encontrar una explicación a los temas que han preocupado al hombre desde el nacimiento de la civilización. El que esas explicaciones se sitúen lejos de la racionalidad que preside la ciencia no quiere decir que estén completamente desprovistas de sentido. Descubrir ese sentido es el objetivo de los estudios de mitología, porque además -presume el mitólogo- ese sentido está entretejido con capas profundas de la cultura, de la mente humana o de la historia (o de la prehistoria como piensan algunos estudiosos), dependiendo en cada caso de dónde se enmarque el estudio. Ver los mitos como simples (o complejas) creaciones literarias es una simplificación impropia de una mente científica. Dios, dijo en alguna ocasión Borges, es la máxima creación de la literatura fantástica. Para el escritor argentino, la teología era un género literario. Pero, no hace falta creer en Dios para darnos cuenta de que en realidad es mucho más que eso, para llegar al convencimiento de que en los mitos de la creación, 
del más allá, etc., se ocultan huellas, vestigios, que enlazan con la psique humana, con los estratos más primitivos pero también con los más modernos de la cultura. Barthes (Mitologies, 1957) nos enseñó que el proceso de creación de mitos no se detiene en la antigüedad, no es una cosa del pasado. Cada día, todos los días, estamos asistiendo a la mitificación de objetos, rituales, individuos que, gracias a la participación de los medios de comunicación de masas, alcanzan ese estado en un tiempo asombrosamente corto. Ya no es necesario el paso de las generaciones sobre un hecho para que este devenga en mito; en cuestión de instantes, Internet es capaz de lograr una penetración social que antes hubiese costado décadas, si no siglos.

La mitología, entendida como repertorio de mitos, no es, no puede ser, solo un prontuario "arqueológico" en el que asomen sus cabezas Thor, Zeus, Siva u Osiris, el martillo encantado, el arca de la alianza o la tabla redonda. Junto a las reliquias mitológicas que han atraído tanto a arqueólogos y antropólogos, se encuentran las novedades, las primicias mitológicas, pasto de semiólogos. Para poder contemplar ese flamante prontuario, para poder proceder al mitoanálisis, no hace falta, pues, ni abrir un libro polvoriento ni visitar un museo antropológico. Basta ahora mismo con encender la televisión, salir a pasear a la calle o recorrer los pasillos de unos grandes almacenes. Allí están, perfectamente alineados, los mitos de nuestra época, los pequeños diosecillos, las nuevas ceremonias, según los cuales ordenamos nuestra vida, enfocamos nuestro comportamiento y damos sentido a nuestra existencia. Deberíamos fijarnos en qué es lo que ocupa en nuestros hogares ese altarcillo antaño habitado por una imagen religiosa, la estampa de un santo o la figura de la Virgen María en escayola pintada: ¿los colores de un club de fútbol? ¿El ordenador? ¿El póster de un cantante de rock? ¿La fotografía de un modelo de automóvil? ¿El receptor de televisión? ¿El ipad?

El proceso de mitificación es un proceso de ficcionalización. Ni por un momento podemos confundir el mito "Maradona" con la persona Maradona, ni podemos confundir el mito "automóvil" con un vehículo de cuatro ruedas con motor de explosión (o eléctrico). El objeto, la persona, la ceremonia, han sufrido un proceso mediante el cual se han vaciado de sus contenidos materiales para 
alcanzar un nuevo estatus, una dimensión inédita. Hay un momento en que se pierde el referente, el objeto, la persona, el acto social han desaparecido para ser sustituido por "otra cosa", por el mito.

El mecanismo que rige el proceso de mitificación massmediático es muy simple, se trata ni más ni menos que el del recurso publicitario (y didáctico) más antiguo: la repetición. La capacidad de los medios de comunicación para repetir "ad nauseam" un acontecimiento, la efigie de un cantante, la imagen de un objeto de consumo, una jugada de fútbol, permite conseguir en unos meses lo que antes sólo era posible en largos plazos de tiempo o quizá en siglos.

Una vez culminado el proceso, del referente no queda más que la cáscara, la apariencia. Aparentemente, pero solo aparentemente, nada ha cambiado en él excepto porque el objeto, el individuo, el acontecimiento, ha sido devorado por su mito. El proceso de mitificación es pues un proceso de autodevoración, un festín caníbal en el que el referente ha sido previamente cocinado por los medios de comunicación de masas, una mutación o una infección que ha ido devorando las "células" del referente mientras éstas iban siendo sustituidas por otras nuevas, creadas desde la pantalla de la televisión, desde la superficie de las vallas publicitarias y desde las "páginas" de Internet. Una vez culminado el proceso lo que queda es un despojo, perfectamente apto para ser clavado en la pared con cuatro chinchetas.

\section{METAS Y MÉTODOS}

Puesto que estamos en disposición de desentrañar los misterios de la naturaleza mediante esas formas de conocimiento que llamamos biología, química, física, geología etc. cuanto mejor estaremos en disposición de desentrañar los misterios de la cultura, los que atañen a las creaciones humanas, tan familiares, en cierto sentido, y tan extrañas en tantos otros. $Y$ sin embargo bien sabemos que no es así. Pasados los fastos del determinismo o del objetivismo, y habiendo regresado, más maltrechos que a la hora de emprender el viaje, a la tierra del relativismo cultural (que es como una formalización del "todo vale" posmoderno), nos encontramos con la conciencia 
de que difícilmente podemos estar seguros de nuestro conocimiento, pero no ya porque no existan principios o valores universales (como defiende el relativismo) sino porque cuanto más seguros estamos de lo que sabemos, menos sabemos.

Hay pues una relación indirecta entre el conocimiento y la certeza del conocimiento, o entre la cantidad y la calidad del conocimiento. Pero también sabemos que en los estudios culturales, cerrar la puerta a la subjetividad, a toda subjetividad, es cerrar la puerta del conocimiento. Dejémosla, pues, entreabierta.

Nuestro objetivo parte de una premisa: la publicidad es creadora de mitos. Esa afirmación la tomamos como una hipótesis de partida que pensamos demostrar a través de algunos ejemplos.

Aún considerando las limitaciones de las ciencia sociales a la hora de establecer un conocimiento seguro, hay una serie de operaciones científicas que están perfectamente a nuestro alcance. Por ejemplo: definir, clasificar, teorizar.

\subsection{Definiciones}

Nuestra primera labor intelectual tiene que ser conocer exactamente la extensión y la comprensión del concepto "mito". Existe no sólo una cierta ambigüedad con respecto al término "mito" (contaminado con la "enfermedad del lenguaje") sino hasta cierta oposición de sentido.

En cierto sentido resulta un término positivo, "persona o cosa rodeada de extraordinaria estima", nos dice el DRAE en una de sus acepciones. En otro es peyorativo: "relato o noticia que desfigura lo que realmente es una cosa y le da la apariencia de ser más valiosa o atractiva", nos dice también el DRAE.

La definición es una operación que tiene lugar en el nivel lingüístico, se realiza por el enunciado del género próximo y la diferencia específica, y se caracteriza por convenir a todo lo definido y sólo a lo definido, por su claridad y brevedad, y porque lo definido quede excluido de la definición. O dicho de forma negativa 
por el rechazo a la ambigüedad, la confusión, la opacidad, lo prolijo y lo tautológico.

Nos valemos, pues, de un término más amplio que aquel que tratamos de definir para, a continuación, restringir su significado con ciertas especificaciones que limitan su aplicación al campo en cuestión.

El mito es un relato alegórico (género próximo) que traduce una generalidad histórica, sociocultural, física o filosófica (diferencia específica). Esta definición me parece lo bastante general como para abarcar muchas clases de mitos, incluidos los publicitarios. Si los anuncios constituyen pequeños relatos cotidianos, ficciones mercantiles, la publicidad constituye un sistema mítico.

En realidad, todos los mensajes publicitarios tradicionales cuentan una misma y sola cosa: la excelencia de la mercancía envuelta, de forma más o menos detallada, en el relato de una búsqueda: la búsqueda del propio objeto (el producto) o la búsqueda de un "estado mítico" de felicidad que se ha venido expresando en una retórica gestual de sonrisas satisfechas y muestras de complacencia burguesa o de bienestar doméstico. Los anuncios gráficos, elípticos, se conformaban con mostrar el aspecto exultante de los consumidores o el aspecto gozoso de las mercancías: los vasos rebosantes de cerveza helada, la presentación sobresignificada de los vehículos y las máquinas, el aspecto crujiente o untuoso de los alimentos, la sonrisa abierta del consumidor, su expresión orgullosa o complacida. Una retórica bastante elemental, a base de signos perfectamente codificados. Los spots, películas y comerciales de televisión, con un desarrollo temporal, permitían un despliegue más detallado de las distintas fases del relato mítico.

\subsection{Clasificación de los mitos}

Clasificar es una operación intelectual que supone el análisis, la comparación y la facultad de hacer abstracción de las diferencias individuales.

Una clasificación tradicional divide a los mitos en:

I. Mitos teogónicos: explican el origen y la historia de los dioses. 
II. Mitos cosmogónicos: explican la creación del mundo.

III. Mitos etiológicos: explican el origen de los seres y de las cosas.

IV. Mitos escatológicos: explican el futuro y el fin del mundo.

V. Mitos morales: Explican el origen de aquellos inventos o técnicas (el fuego, los alimentos, la escritura, etc.) particularmente importantes para un grupo social.

La capacidad mitificadora y fabuladora del ser humano no se ha detenido ante la llegada de un mundo moderno y tecnológico. Recordemos, a manera de ejemplo, esa corriente que existe desde hace décadas y que trata de explicar el origen de determinadas creaciones humanas -las pirámides de Egipto, las estatuas de la isla de Pascua- estableciendo que han sido obra de jextraterrestres! Es decir, explicando un hecho con un mito, en vez de lo contrario (que suele ser lo habitual): explicar un mito con un hecho acaecido. No obstante, este tipo de creencias demuestran algo importante: una línea continua desde el pensamiento mítico primitivo al moderno; lo único que se ha hecho es sustituir a los dioses (muy faltos de prestigio en las últimas décadas) por los extraterrestres, mitos más apropiados en una sociedad tecnológica, en la que la ciencia goza de gran autoridad. Con respecto a ellos (a esos quiméricos "visitantes"), incluyen todas las características del mito clásico: estuvieron aquí en un pasado muy lejano, realizaron grandes proezas de las que sólo nos han llegado algunas muestras, regresarán algún día. La diferencia es que no se les espera montados en un carro de fuego, sino en una nave interestelar. Dioses o extraterrestres forman parte, en cualquier caso, de ese pasado "lejano y prestigioso" característico del pensamiento mítico.

Esta clasificación nos parece, no obstante, demasiado encajada en un escenario premoderno, en el que el comportamiento presente está siempre regido por el pasado: todo lo que se hace en el presente es un reflejo de lo acaecido en el pasado. No sirve, pienso, para un escenario moderno, regido por la idea de progreso; ni posmoderno, regido por el "aquí y ahora".

Hay más clasificaciones de los mitos, por ejemplo por su escenario geográfico: mitos grecorromanos, hebreos, egipcios, hindúes, nórdicos, etc. Todavía nos 
parece menos significativa para nuestros objetivos. Vamos a ofrecer nuestra propia taxonomía:

I. Mitos del pasado: tienden a explicar nuestro origen y el de nuestro entorno. En este apartado entrarían todos los anteriores excepto los escatológicos.

II. Mitos del futuro: tienden a explicar nuestro porvenir y el de nuestro entorno. Aquí se situarían no sólo los mitos escatológicos clásicos, también una gran parte de esa rama de la literatura conocida como ciencia ficción que (y eso es lo que diferencia al mito del cuento) no tiene como objetivo sólo el entretenimiento. Es lo que se ha llamado, sin demasiado éxito, "ficción especulativa”. La diferencia entre los mitos escatológicos clásicos y los nuevos mitos "científicos", estaría en que mientras los primeros ofrecen una explicación astrológica o esotérica, los segundos la ofrecen tecnológica. Un buen ejemplo son las novelas apocalípticas del británico J. G. Ballard. Al igual que en los mitos escatológicos, el fin del mundo (al menos el fin de nuestro mundo) tiene, en los relatos del autor británico, su origen en el agua (El mundo sumergido, 1962), el viento (El viento de ninguna parte, 1962) o el fuego (aunque no en un sentido literal: La sequía, 1965) pero ello es explicado mediante un determinismo tecnológico. Aunque, así mismo, son los pecados de los hombres -si bien en este caso se trata de "pecados ecológicos"- los causantes del desastre.

Es verdad que no todos los mitos escatológicos se sitúan en el porvenir. Dentro de su concepción del universo, el fin del mundo ya se ha producido (el Diluvio Universal, por ejemplo) pero volverá a reproducirse en el futuro, precedido por una Edad de Oro, tal y como ocurre cada año con la naturaleza, manifestando la condición cíclica de algunos mitos.

III. Mitos del presente: tienden a explicar nuestro comportamiento, nuestros hábitos, nuestros rituales, sin necesidad de remontarse a un pasado "lejano y prestigioso" sino mediante la presencia de figuras míticas en nuestro entorno cultural. Son más difíciles de detectar, pasan fácilmente desapercibidos pues, desde esta perspectiva, nos encontraríamos sumergidos en una sopa 
mitológica dentro de la que se producen nuestros movimientos (la compra, el voto, las formas de ocio, nuestros hábitos y rituales contemporáneos), pero también son los de estudio más interesante. Pasan por ser construcciones "naturales", sucesos inefables, cuando se trata de construcciones míticas, culturales ${ }^{2}$.

Todos ellos tienden a dar cohesión a una sociedad o cultura. No sólo los del presente. Todos proporcionan pautas de comportamiento. Ahora bien, puesto que hablamos de mitos publicitarios, los que nos interesan son aquellos que nos proporcionan pautas de consumo.

\subsection{Teorizar}

No hay nada más práctico -dijo en memorable ocasión el psicólogo social Kurt Lewin- que una buena teoría. Necesitamos teorías, el conocimiento científico debe ofrecernos explicaciones teóricas de cómo se relacionan entre sí los fenómenos. Necesitamos teorías para explicar en qué se basa la actividad de la publicidad, sus mecanismos de funcionamiento, su eficacia.

Aunque quizá ese propósito desborde un tanto las dimensiones y posibilidades de un artículo, la obligación es cuando menos proponerlo. Si la publicidad quiere convertirse en una ciencia, y no meramente en un conocimiento empírico, hay que ofrecer explicaciones a las cosas que suceden en ella.

En realidad, y dado el grado de desarrollo epistemológico de la publicidad, lo suyo sería ofrecer diferentes teorías, desde distintas disciplinas científicas, tendentes a explicar sus procedimientos. Es obvio, por lo señalado, que aquí nos conformaremos con una única propuesta, que deberá ser evaluada no en función de que sea verdad o mentira (esos son conceptos morales) sino en la medida en que es o no es explicativa del fenómeno en consideración. Lo cierto es que la perspectiva que hemos adoptado viene amparada por un hecho: el objetivo del estudio de los mitos es el de la compresión de la cultura, y la publicidad es uno de los ingredientes fundamentales de nuestra cultura.

\footnotetext{
2 "El mito consiste en hacer de la cultura naturaleza, o al menos en convertir en "natural" lo social, lo cultural, lo ideológico, lo histórico" (Barthes: 1987: 83)
} 


\subsection{La claridad como requisito}

Colocábamos antes la claridad como una exigencia de la definición. Creo que este requisito debe extenderse a todo el trabajo científico, no puede entenderse la investigación sino como una aportación de luz a alguna zona oscura del saber. Refugiarse en un lenguaje críptico, en una erudición pintoresca, en un discurso amanerado, prolijo o artificioso es huir del problema básico de la ciencia. Construir un discurso todavía más confuso u oscuro que aquel que se quiere elucidar puede servir como ejercicio de estilo, pero como creación de conocimiento estará siempre bajo sospecha.

El conocimiento científico se opone así al conocimiento esotérico. La explicación debe ser más clara, más plausible, más racional, que lo explicado. Decir que las pirámides mayas o egipcias las construyeron los extraterrestres, sólo porque nos cuesta explicar como pudieron ser construidas por seres humanos de una determinada época y lugar, es hacer todavía más oscuro el fenómeno a explicar. La explicación esotérica no solo demuestra debilidad empírica, también debilidad racional.

La definición clásica de publicidad es la de "ciencia y arte de vender". Cuando una actividad se define como "arte y ciencia", normalmente no es ni lo uno ni lo otro. En esa definición se expresa más una impotencia que una auténtica elucidación del fenómeno estudiado; se manifiesta, en todo caso, una aspiración de rigor (la ciencia) y una conciencia de que existe un cierto grado de descontrol resuelto mediante la intuición o el oficio (el arte).

Entender la publicidad como una forma de ficción mítica, un relato mítico, nos ayuda a explicar su funcionamiento. La publicidad es eficaz en la medida en que emplea unos recursos (los mecanismos del mito) que han servido, desde los albores de la civilización, para ajustar el comportamiento de los ciudadanos a una situación, a un estado de cosas que, en nuestro caso, es el de una civilización del consumo. La forma de perpetuarse que tiene esa civilización es mediante el recurso a una serie de relatos míticos que llamamos anuncios 0 
publicidad, por el cual existe un mundo mejor (un paraíso burgués) que se pone a nuestro alcance a través de las mercancías.

\subsection{La búsqueda del significado}

La mitología (aquí entendida como conocimiento de los mitos, no como colección de ellos) concebida como la búsqueda del significado de los mitos.

Para ello fijamos la atención en los temas y los símbolos que aparecen en los mensajes publicitarios, pero también podemos encontrar significado en los aspectos formales.

El salto definitivo en el estudio de los mitos se dio, precisamente, a partir de la consideración de que éstos no eran simplemente una colección de relatos sin sentido, narraciones absurdas o puras ficciones Propias de una civilización en un estado todavía infantil, sino construcciones que reflejaban hechos acaecidos o instituciones que formaban parte del pasado. Aunque Freud interpretó los mitos como concesiones substanciales a la fantasía (y, por tanto, semejantes a los sueños) la idea dominante es la de que poseen una funcionalidad: explicar acontecimientos que se escapan al control humano y proporcionar pautas de comportamiento.

Es más, para Lévi-Strauss el significado era el fundamento de los mitos, la sustancia de la que estaban forjados: "En música es el elemento sonoro el que predomina, y en el mito es el significado" (Lévi-Strauss: 1987: 76).O, por decirlo de otra manera, la música tiende a la forma pura, y el mito al puro contenido.

Tomemos uno de los mitos más representativos de la publicidad española: el toro de Osborne. Como sabemos, este símbolo fue creado por el dibujante Manolo Prieto y la agencia Azor (Fig. 1). Representa la silueta negra de un toro, recortado en chapa metálica, con unas dimensiones de 11,50 x 5,40 metros, y ubicado originalmente al borde las carreteras. 


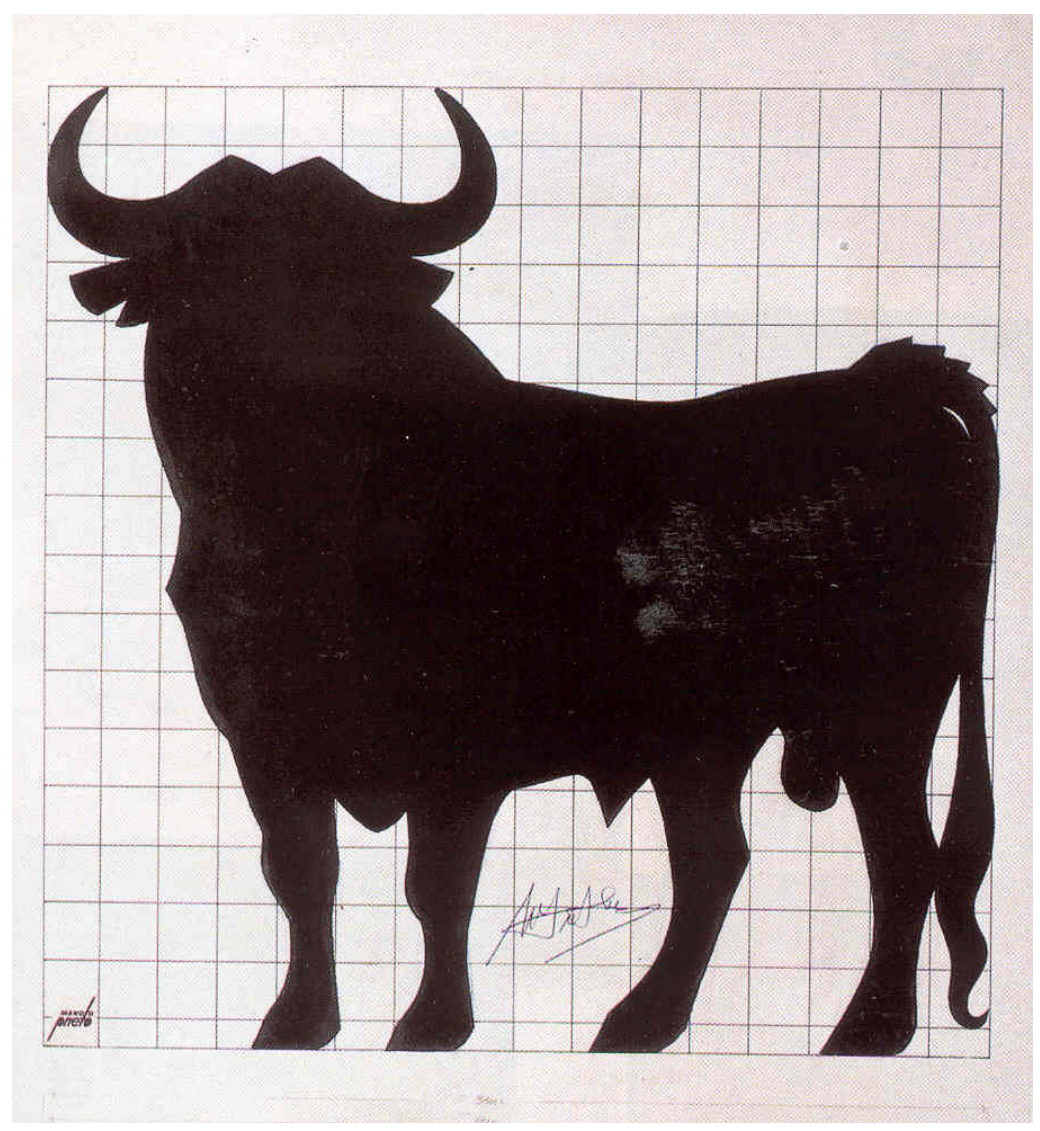

Fig. 1. Toro de Osborne. Diseño de Manolo Prieto. 1956

Curiosamente este emblema de una compañía de vinos y licores pasó de ser un signo puramente publicitario (representante de una marca comercial) a convertirse en un mito de carácter social. Los mitos contemporáneos parecen operar en un determinado entorno, hay mitos del deporte, mitos cinematográficos o mitos publicitarios, pero no todos desbordan los límites del entorno que le es propio. En cierta forma, el público, en el caso del toro de Osborne, había relegado su función comercial para recubrirlo de valores de otro tipo: formaba parte de nuestra cultura, de nuestro repertorio de símbolos patrios, incluso para muchas personas nada taurófilas.

Como mito publicitario proporcionaba una pauta de consumo. El toro, en las culturas mediterráneas siempre ha estado rodeado de connotaciones positivas: fuerza, masculinidad, nobleza (si se trata de los toros de lidia), etc. El buey Apis de los egipcios, por ejemplo, era símbolo de la energía procreadora y de la fecundidad. Sin entrar en el detalle de todos los significados ligados al toro, 
algunos contradictorios (lunar-solar, masculino-femenino), lo cierto es que los creadores del emblema eligieron para representar a la marca Osborne un símbolo de gran riqueza y antigüedad, con lo que ello conlleva de ventaja, pero también de riesgo.

El hecho es que el toro de Osborne presenta así un triple nivel de significación, y no uno doble como ponía en evidencia Barthes en sus Mitologías.

1. Un primer significado literal. Ese trozo de chapa metálica recortada en cierta forma (significante) representa al toro, a un toro o a todos los toros (significado) pues en él reconocemos aquellos estigmas que lo identifican: el rabo y las cuatro patas, el cuello poderosísimo, los cuernos, etc.

Ahora bien este primer signo es, a su vez, el significante de un nuevo significado: la marca Osborne. Es el significado publicitario que es simultáneo y no sucesivo del anterior. Yo capto a un tiempo los dos niveles: es un toro y es Osborne. Aunque no todos los toros poseen este significado; sólo el conocido como toro de Osborne, cuyo significante es reconocible y perfectamente diferenciable de otros significantes que encierran así mismo el significado "toro".

Pero al haber adquirido una nueva dimensión social, existe todavía un tercer nivel de significado, un significado social. Este toro (no cualquier toro, sino sólo ese), que también es Osborne, representa a España, a unos supuestos valores que se ocultan bajo la palabra "España". En realidad, pasa de ser algo concreto, un toro, una marca comercial, a constituir una abstracción, un conjunto de asociaciones, bastante subjetivas y difíciles de concretar, referidas a una nación.

La demostración empírica de que se había convertido en "otra cosa", en un mito, se manifestó en la resistencia social, cultural y política (la Junta de Andalucía pidió su calificación como "bien cultural" y la Comunidad Foral de Navarra se amparó en una ley foral para protegerlo en su territorio), cuando el gobierno obligó a la retirada de las vallas publicitarias de las carreteras. Tras un juicio, el toro fue "indultado" por el Tribunal Supremo, rindiéndose así a una evidencia: su evolución desde un simple emblema comercial a un símbolo de 
carácter nacional, a un dispositivo que formaba parte de la cultura de un país. Ya no era publicidad, ya era cultura.

Los atentados antiespañolistas contra él demuestran el poder del mito. Y lo que consiguen, obviamente, es reforzarlo en su carácter de mito nacional.

Otra demostración del valor universal de este mito contemporáneo: en Copenhague, ha sido elegido para representar a España en el Superkilen Park, un parque dedicado a la diversidad cultural. Los vecinos de la zona aledaña al parque fueron consultados sobre los símbolos que debían formar parte de este parque, representando a las distintas culturas, el resultado es una mezcla que incluye palmeras chinas, bancos de barra brasileños, mesas de picnic búlgaras, cedros de Liberia, un portabicicletas noruego o una barbacoa argentina, junto al toro de Osborne.

Naturalmente, el hecho de que haya sido declarado un artefacto cultural no barre su sentido publicitario: es capaz de provocar ciertos comportamientos sociales, a favor o en contra de su figura, pero también sigue proporcionando pautas de consumo.

\section{EL RELATO MÍTICO}

Una gran parte de los mitos contemporáneos no son en realidad sino actualizaciones inmediatas de mitos antiguos. El cine, el cómic, la novela popular y la publicidad reproducen los mismos esquemas de viejos mitos: dioses y héroes, la lucha entre las fuerzas del bien y el mal, entre la luz y la oscuridad (o, en términos publicitarios, entre la limpieza y la suciedad), reaparecen en personajes como Superman, Indiana Jones, Spiderman, en las situaciones recreadas por filmes policíacos o por westerns, en las tramas de los anuncios televisivos.

Me explicaré con algunos ejemplos: Superman, que surgió en Estados Unidos muy oportunamente, en la época de la Gran Depresión, tenía, como es característico en muchos héroes mitológicos, un pasado modesto y una identidad oculta. Al igual que Moisés, había sido abandonado a las procelosas 
corrientes, en este caso, estelares. Había sido educado por alguien que no era su padre auténtico y llegaba para salvar a la Tierra de sus miserias.

Hoy día los héroes son los deportistas, esos "personajes excepcionales" que prestan modelos a imitar y que ponen en funcionamiento las nostalgias secretas de sus seguidores. Muchos de ellos tienen un origen modesto, son chicos de pueblo, han sido educados fuera de su entorno familiar, en el club deportivo, para convertirse finalmente en héroes massmediáticos.

En un anuncio comercial podemos leer lo siguiente: "Se crió en los bajos fondos. Maduró en los ambientes más lúgubres. Pero consiguió triunfar en la vida".

El héroe logra superar todas las adversidades, a pesar de unos orígenes modestos u oscuros; logra levantarse allí donde otros caen, y tiene un destino que cumplir.

El anuncio sigue: "Si está pensando en un futbolista, se equivoca". 


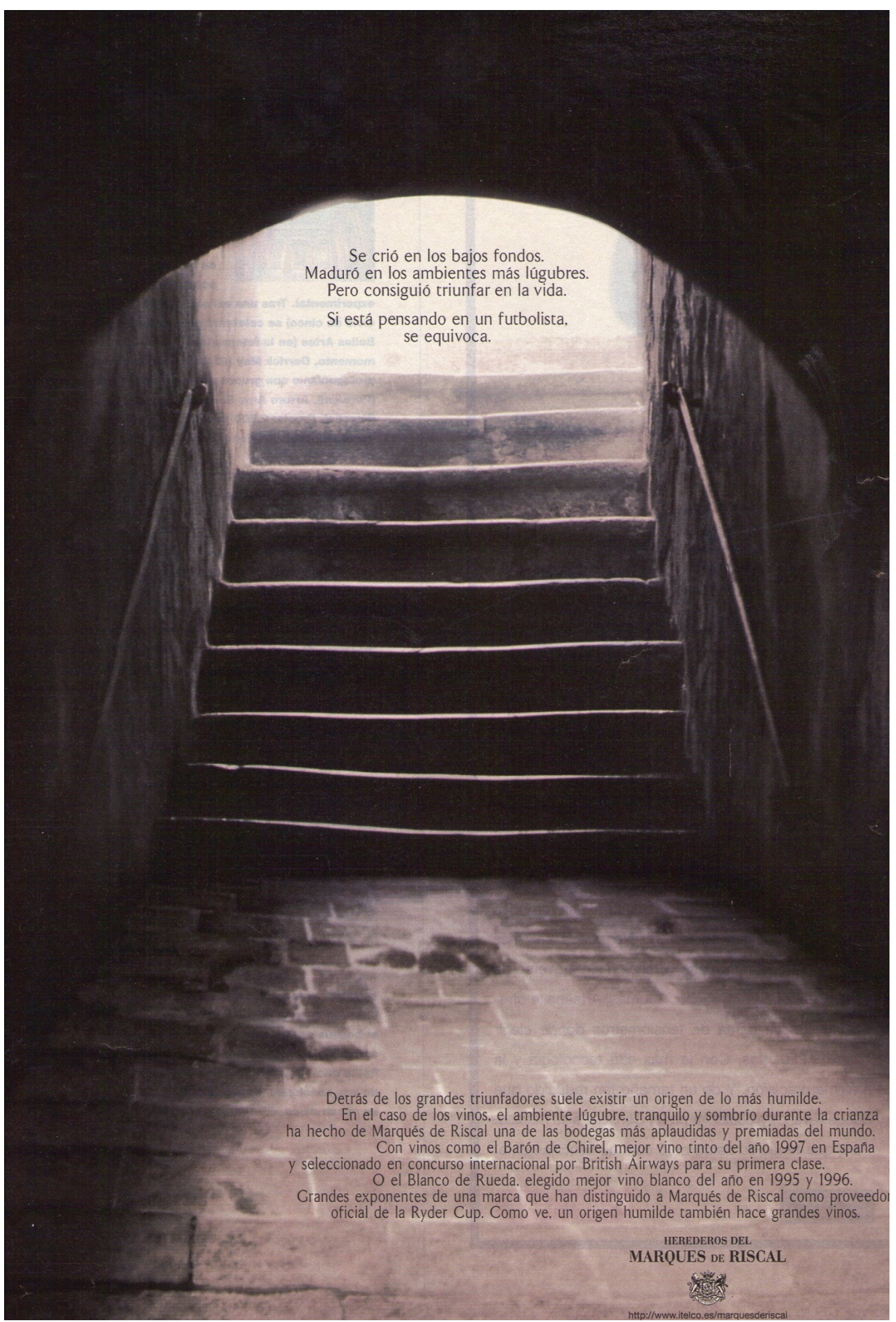

Fig. 2. Bodegas Marques de Riscal, c. 1998

REDMARKA UIMA-Universidad de A Coruña - CIECID

Año V, Número 9, (2012), v1 pp. 91-129

http://www.redmarka.org/

ISSN 1852-2300 
El producto es un vino (Fig. 2). Pero el hecho es que, como dice el mensaje: "Detrás de los grandes triunfadores suele existir un origen de lo más humilde". Esto, si pensamos un poco, casa divinamente con el mito del ascenso social, del hombre hecho a sí mismo, tan propio de la mentalidad capitalista. "Se descubrirán comportamientos míticos -nos señala Mircea Eliade- en la obsesión del "éxito", tan característica de la sociedad moderna, y que traduce el oscuro deseo de trascender los límites en la condición humana" (Eliade: 1973: 204).

Esa "obsesión del éxito" es, en verdad, uno de los mecanismos recurrentes que subyace al discurso publicitario. Los anuncios emplean a menudo una estructura muy semejante, por no decir idéntica, a la del relato mítico, con su héroe (el consumidor), su objeto mágico (el producto) y su meta (la blancura de la ropa, la envidia de los vecinos, el éxito social, la autorrealización del protagonista).

Este héroe posmoderno y consumista debe emprender la difícil búsqueda del objeto encantado (el producto anunciado) entre los atestados anaqueles del supermercado, en las calles de una populosa ciudad, repleta de señales confusas y de llamadas interesadas que intentan distraerle de su "sagrada" misión, de su lucha contra las fuerzas de la "oscuridad", en forma de manchas, frustración, mal olor corporal, rechazo social, caspa o cualquier otra adversidad cotidiana.

Hay fuerzas que se oponen: los productos de la competencia con los que nunca podrá obtener el efecto deseado; que intentan, al igual que sirenas en un océano de mensajes, llevarle a la perdición. Pero con frecuencia cuenta con la ayuda de algún ser mágico (una mascota publicitaria como el "osito de Mimosin", un personaje fantástico tipo "el hombre blanco de Colón") que aparece misteriosamente en el momento en que más se le necesita (como el "mayordomo de Tenn") dispuesto a resolver los problemas del héroe o heroína, y que es aceptado por él o ella sin ningún sobresalto, sin ninguna contradicción 
con respecto a la estructura del relato, precisamente porque los anuncios, los relatos publicitarios, forman parte del gran corpus de las narraciones míticas.

Por eso también es difícil acusar a la publicidad de falaz, exagerada o tramposa, porque su lógica no es la del mundo cotidiano, sino la del universo de los mitos. En la medida en que se trata de una ficción, nada impide que los coches vuelen, los grotescos seduzcan a las bellas sin más herramienta que un desodorante o que (Fig. 3) las tablas de una tarima se eleven mágicamente como una escalera hacia el cielo. 


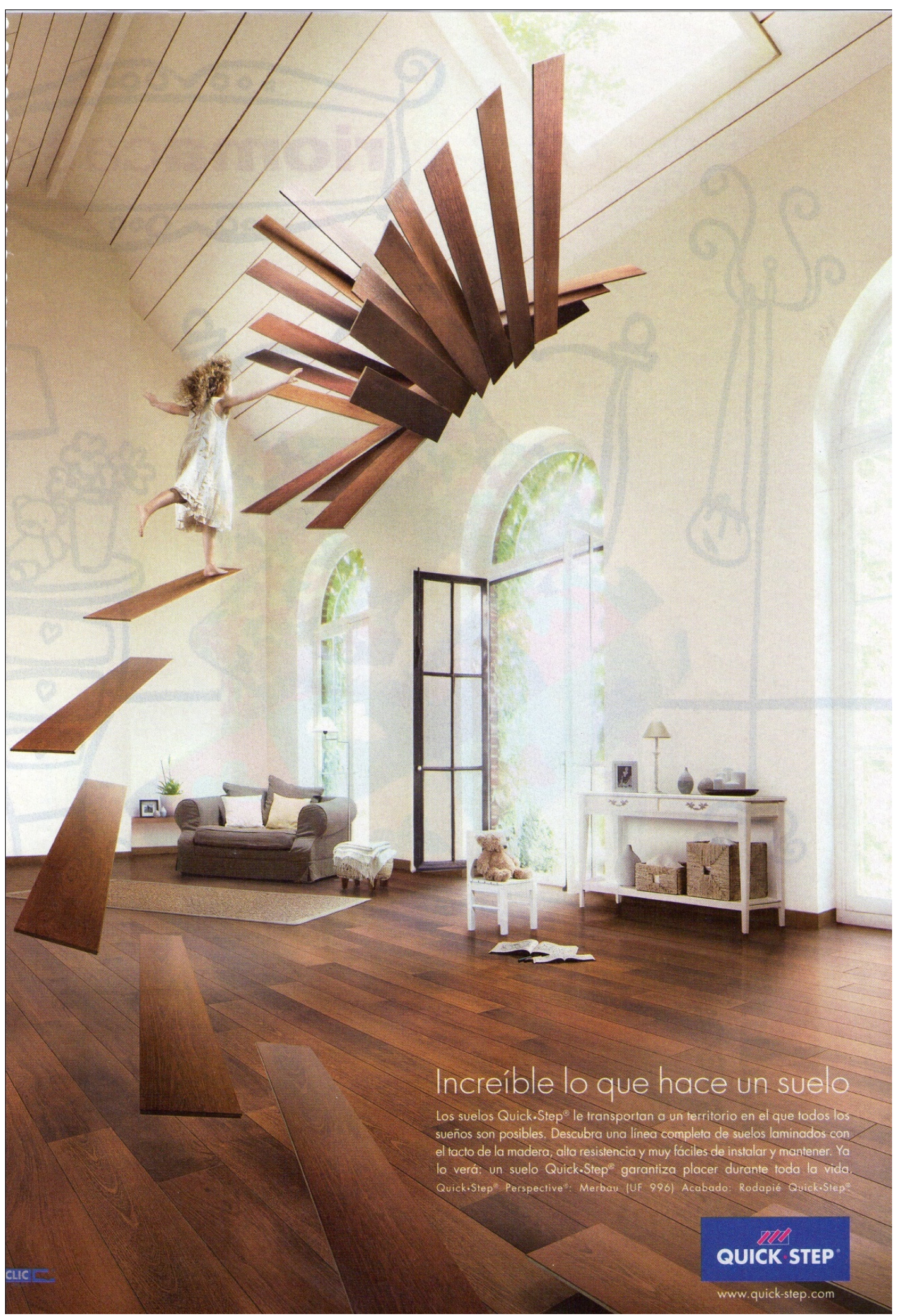

Fig. 3. Anuncio gráfico Quick.Step. 2008 
No hay tal trampa, siempre y cuando la publicidad se reconozca como tal; es decir, como una ficción mítica. Y siempre que el espectador esté dotado de la necesaria competencia para distinguir entre la realidad y la ficción; por ello es la infancia, el sector poblacional más sensible, más permeable a la publicidad, al no haber adquirido aún la competencia necesaria para hacer la debida distinción entre el mundo real y el de las ficciones.

Como todos los mitos, la publicidad es un tipo de ficción que no tiene una mera función de entretener (aunque en ocasiones lo haga) sino la de proporcionar un sentido a la sociedad del consumo (más allá de su pura funcionalidad mercantil). Los cuentos entretienen, divierten, conmueven, los mitos crean sentido. El anuncio de la Fig. 3, podría parecer un cuento de hadas, pero es mucho más que eso. No hay en él inocencia ninguna, sino intención, sentido. La intención de vender una mercancía. El sentido que es propio del discurso publicitario.

\subsection{El reino mítico publicitario}

Una de las características más constantes de los mitos primitivos, compartida por diferentes culturas, es el regreso de una época feliz, un período de esplendor y abundancia normalmente tras pasar por una época de grandes calamidades, cataclismos, un diluvio (recogido en diversas tradiciones), hecatombes capaces de barrer de la faz de la tierra a un raza decadente y pecadora, y a la que seguirá una nueva creación. No es algo exclusivo de las creencias "primitivas" o ágrafas, para la religión hebrea ese regreso al Paraíso se producirá con la llegada del Mesías ${ }^{3}$ y para el cristianismo con el Juicio Final y la segunda venida de Cristo.

Habitualmente, se interpreta que este mito de la renovación, del regreso de una Edad de Oro, proviene de un hecho observado en la naturaleza: el paso de las estaciones y el renacimiento que se produce con la llegada de la primavera. Este mecanismo consolador de las penurias presentes es, en realidad, el

\footnotetext{
${ }^{3}$ Según Marvin Harris, la creencia en el mesías responde a la aspiración de libertad del pueblo judío. No es el mesías pacifista del cristianismo, sino un guerrero y un libertador. (Véase Harris: 1985: 139 y ss.)
} 
mismo tipo de dispositivo que emplea la mitología publicitaria. También aquí existe la promesa de un reino feliz, un escenario de abundancia y de confort al modo burgués. Y en este caso el Mesías que ha de llegar para liberarnos es, ni más ni menos, que el producto. La tradición iconográfica publicitaria está saturada de signos de felicidad, sonrisas satisfechas, gestos de complacencia, escenas de bienestar, signos de triunfo, de éxito social. Sólo que esa promesa no se satisface en un futuro remoto y legendario, sino en el "aquí y ahora" que es propio de las sociedades posmodernas.

En algunos casos (Fig. 4), se recurre a propuestas muy literales, un calzado nos devuelve al Paraíso (un Paraíso sin serpiente, por supuesto). 


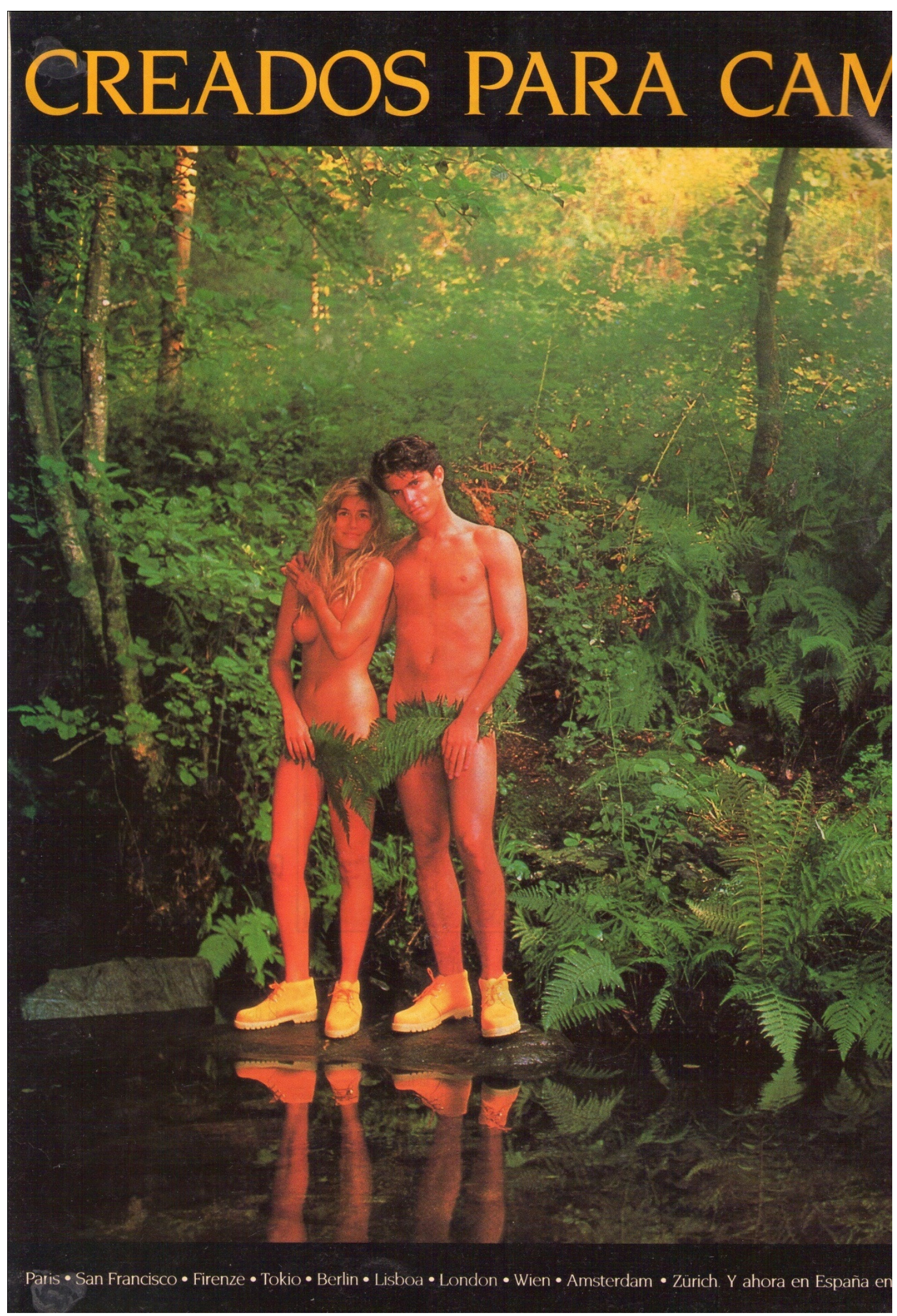

Fig. 4. Calzado Panama Jack, c.2000

REDMARKA UIMA-Universidad de A Coruña - CIECID

Año V, Número 9, (2012), v1 pp. 91-129

http://www.redmarka.org/

ISSN 1852-2300 
En realidad no existe una manera única de expresar ese lugar mítico, porque hay muchas formas de entender la felicidad. Tanto puede ser una playa salvaje y solitaria, como una escena de confort familiar. No obstante, también existen los casos en los que tan sólo se muestra el producto (Fig. 5) eso sí, ennoblecido por el Photoshop, rodeado de un aura, omnipotente y absolutamente deseable; inserto en algo así como un espacio cósmico, sobrenatural, glorioso. 


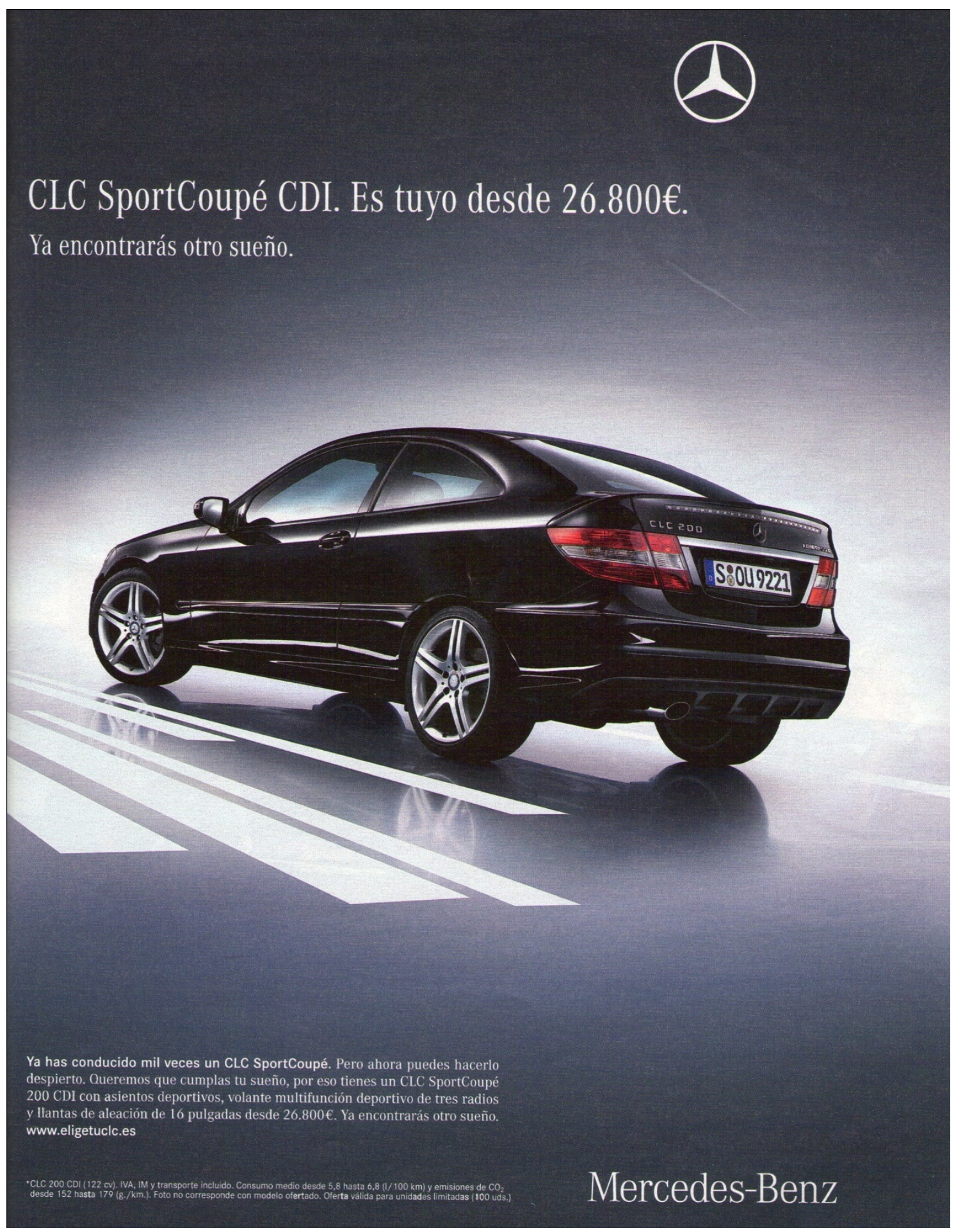

Fig. 5. Mercedes-Benz. 2009

En estos casos, el Paraíso es el propio objeto. No hay, no puede haber, una mayor plenitud que la emanada de la propia posesión del producto. Más allá no hay nada, ni naturaleza salvaje, ni felicidad doméstica. Tan sólo vacío. 
Ese escenario ideal publicitario, reino de satisfacciones plenas, de alegría desbordante, de aspiraciones complacidas, frigoríficos colmados de mercancías, hombres y mujeres que de tan perfectos son irreales, al igual que príncipes y hadas de cuento, rebosante de signos de complacencia, nos indica que ese reino que debemos conquistar se parece extraordinariamente al regreso a la infancia, entendida como tiempo pleno o terreno mítico. Un estado libre de frustraciones, saciado y mágico.

En una carta al crítico y ensayista Andrzej Plesniewicz, el escritor polaco Bruno Schultz (2008: 87) expresaba lo siguiente: "Si se pudiera invertir el curso de la evolución, y regresar a la infancia por senderos desviados, gozar una vez más de su plenitud y su inmensidad veríamos finalmente cumplida esa "época genial", esos "tiempos mesiánicos" que las mitologías siempre nos han prometido e, incluso, afirmado su advenimiento". La infancia es, en verdad, lo más parecido al Paraíso que conoce el hombre, así que no es de extrañar que el mundo publicitario sea un escenario pueril, infantilizado; y que su éxito se apoye en esa nostalgia del reino mítico de la infancia.

Quizá el período donde mejor se manifestó esa especie de Disneylandia del consumo, fue en los finales cincuenta y primeros sesenta, la Edad de Oro de la publicidad, en la que los anuncios americanos ofrecían todo tipo de mercancías -en las que dominaba el color rosa: frigoríficos, tostadoras, aparatos de radio, lavadoras, hornos, todos en el color de los sueños-; automóviles desproporcionadamente grandes y aparatosos, como astronaves de combate; helados, tartas, pasteles recubiertos de crema o merengue de color rosa, adornados con guindas y chorros de caramelo; interiores cómodos y espaciosos, amueblados con amplios divanes, alfombras y lámparas; todo ello ofrecido en mensajes saturados de color.

El reino mítico publicitario sigue siendo hoy un escenario pueril, aunque saturado de tecnología. Está lleno de pantallas, servomecanismos, controles y dispositivos. Hay un mito del ordenador, de la computadora, que hace que cafeteras, lavadoras y hornos microondas adopten su morfología: controles táctiles, cuadros digitales, programadores. Si antaño la fisonomía del coche era 
la de una astronave, hoy es su interior el que adopta esa mitología espacial, provisto de pantallitas, indicadores luminosos y todo tipo de gadgets.

\subsection{La eficacia de la publicidad}

Hay distintas formas de evaluar la eficacia de la publicidad, pero dos han sido más dominantes. La primera es mediante el recuerdo, destaca en este caso el aspecto comunicativo de la publicidad. Aunque, en verdad, no necesariamente un anuncio que haya tenido una gran penetración entre la población ha generado necesariamente más ventas. La segunda, parte de una concepción marquetiniana de la publicidad, más que comunicativa: las ventas. Un anuncio es mejor cuantas más ventas genera. Aunque, bien sabemos que la venta depende de otros factores (distribución, precio, producto, promociones, diseño, etc.) y no únicamente de la publicidad. Es difícil establecer una ecuación que relacione directamente publicidad y ventas. Además hay que tener en cuenta el efecto acumulado de la publicidad, una venta no está determinada sólo por la última campaña, influyen también todas las anteriores que se hayan hecho.

Cuando Wanamaker dijo su famosa frase: "la mitad de la publicidad que hago no sirve para nada, lo malo es que no sé qué mitad", probablemente estaba siendo muy optimista. Ahora bien, el problema empieza en otro lado, no en saber qué mitad no sirve para nada, sino en saber por qué una parte de la publicidad (sea la mitad o la cuarta parte) sirve para algo.

Volviendo al planteamiento original. En un entorno mítico tradicional, el individuo se encuentra aprisionado por el poder sagrado y sublime de los sucesos recordados o actualizados. De la misma forma, el individuo contemporáneo se encuentra aprisionado por un poder que, en este caso, no es sagrado ni sublime, sino tecnológico (los medios de comunicación de masas) y retórico (las ficciones publicitarias). El poder de la publicidad no es un poder trascendente, a pesar de que también es capaz de condenarnos a ciertos infiernos modernos (la suciedad, el rechazo social...). Se basa en la capacidad de penetración, repetición y difusión masiva de ciertos dispositivos 
(televisión, Internet) y en una serie de mecanismos comunicativos clásicos (la retórica, la persuasión, la seducción), pero de probada eficacia.

Que la publicidad utilice más el "infierno" que el "paraíso" en su retórica, depende del momento social. En los años treinta era bastante habitual la publicidad de tipo "amenaza", un mal aliento podía hacernos perder el trabajo, la falta de un seguro podía condenar a nuestra familia a la miseria. Actualmente, en una nueva época de crisis, ocurre algo semejante: un detector de radares para el coche se vende, por ejemplo, bajo la amenaza de que nos pueden llover las multas, y perder el sueldo en infracciones de tráfico. Es un método eficaz y terrible, propio de una época de miedo. No un miedo ante una amenaza más o menos lejana y difusa (el cataclismo ecológico, la hecatombe nuclear) sino el miedo próximo y concreto a perder el trabajo, los ahorros, la vivienda.

La publicidad, el cine, la televisión traducen esos miedos, sustituyen esos miedos reales por otros ficticios, recurriendo muchas veces a una mitología de origen romántico y esotérico (el vampiro, el zombi, la momia o el hombre-lobo) que se encuentra sorprendentemente reactualizada. De la misma forma que existe un resurgir de los adivinos, astrólogos, pronosticadores y videntes. Veamos un ejemplo. 


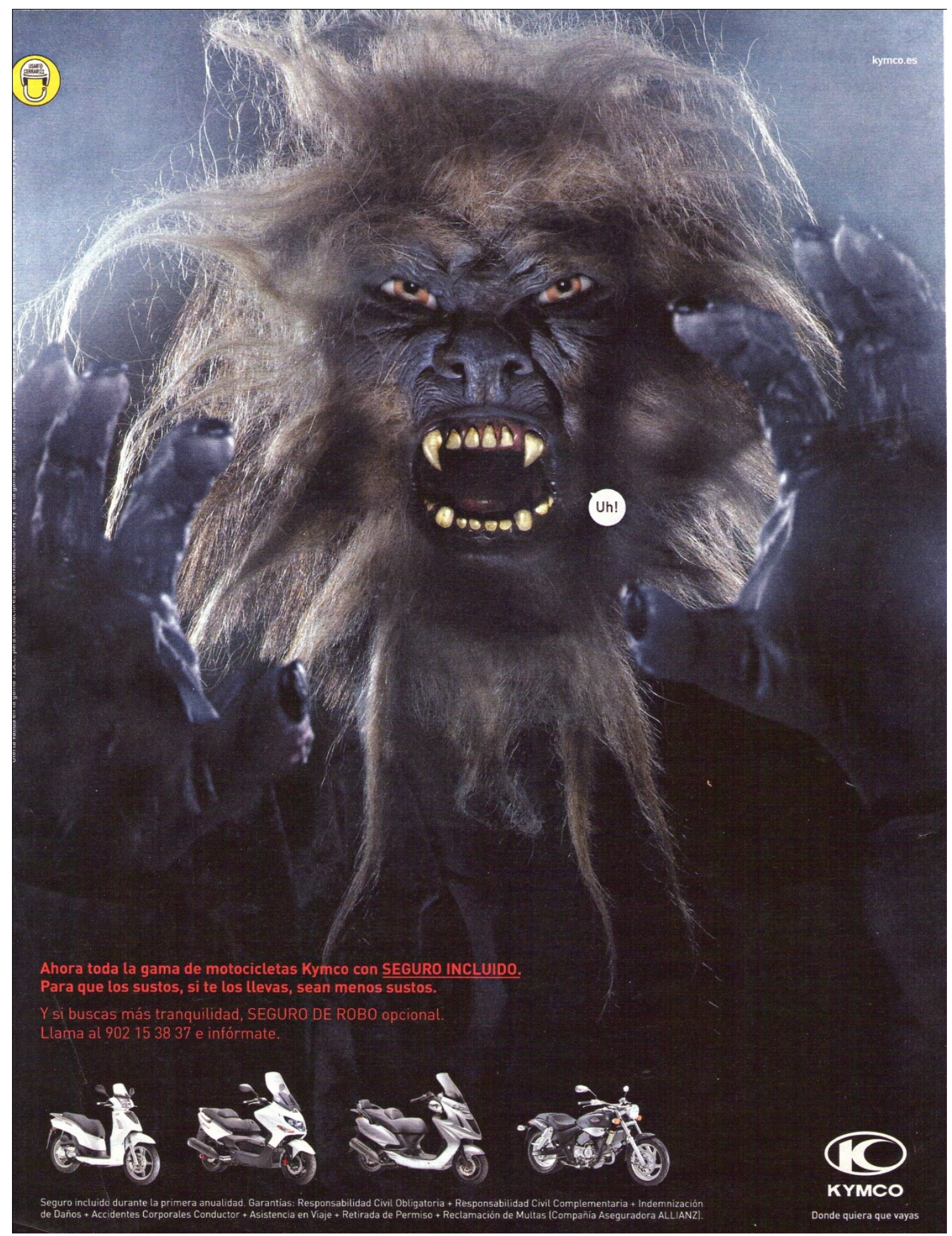

Fig. 6. Motocicletas Kimco. 2008

El anuncio de la Fig. 6 recurre a un clásico de la literatura y el cine de terror: el hombre-lobo. ¿Por qué la publicidad actual olvida su ingenuidad primigenia, su 
retórica complaciente, para emplear un recurso aparentemente tan poco "publicitario"? Hay dos factores que nos pueden ayudar a comprender el mensaje. Primero, una tendencia de la publicidad de los últimos años a no parecer publicidad. Cualquier cosa que evidencia muy a las claras su pertenencia al género publicitario, no puede ser buena publicidad. La publicidad tiene que parecerse menos a la publicidad y más al arte, al deporte, a la moda o al cine de terror. Segundo, el momento histórico del anuncio; 2008, es el año de la catástrofe económica y del arranque de una nueva época de temor. Ahora bien, pasado el primer susto, pronto podremos advertir que el mensaje, en realidad, no abandona el tono gozoso que caracteriza a la publicidad. Realmente se trata de un mensaje con un trasfondo humorístico: el monstruo emite un pequeño "Uh!" en forma de bocadillo de cómic, casi imperceptible; aparece a la derecha de las fauces abiertas, haciendo con ellas "gracioso" contraste. El texto refuerza el sentido paródico del anuncio: "Para que los sustos, si te los llevas, sean menos sustos". Nada que ver, pues, con aquellos anuncios del año 29, en los que los seguros se vendían con amenazas de embargos, y escenas de colegiales buscando trabajo en las oficinas de empleo.

El entorno tecnológico no ha atenuado la eficacia de los mitos. Bien al contrario, nos encontramos ante las máquinas como los antiguos ante los dioses, los brujos o los espíritus. Al común de los mortales nos resultan tan incomprensibles como antes parecían las fuerzas de la naturaleza. Nuestras reacciones ante las máquinas son íntegramente emocionales, carecemos por completo de competencia para juzgarlas, son fuerzas del "más allá". No comprendemos nada de su funcionamiento interno, y nuestras decisiones se basan más en su aspecto externo que en su mecánica o su electrónica. Por eso también los anuncios no se molestan, por lo general, en hablarnos de sus características internas, sus prestaciones, y se conforman con una presentación sobresignificada del producto: una iluminación cenital, un encuadre que magnifique su aspecto, etc.

Un perfume, un automóvil, una marca de whisky, aparecen así ante nuestros ojos como objetos caídos del cielo, rodeados de un aura, como los santos, resplandeciendo como los ángeles. Es el poder mitificador de la publicidad. 
Qué nos importa para qué sirvan; son hermosos, son deseables, son poderosos (o, al menos, lo parecen), nos proporcionan seguridad, confianza, certeza. La publicidad, al igual que la religión, es una cuestión de fe.

La aspiración del anunciante de hoy no es simplemente la de que compres su producto -generar, en alguna ocasión concreta, un acto de compra, no parece algo tan difícil- sino que creas realmente en él. Solamente así, se asegurará de que tu acercamiento a su mercancía no sea flor de un día, pan para hoy y hambre para mañana; es necesario que responda a una costumbre o mejor a una fe en sus productos. Es lo que se llama "fidelidad a las marcas". Uno tiene que "ser" de Coca-Cola o de Pepsi, de Nike o de Adidas, de Mercedes o de BMW, de la misma forma que se es de un equipo de fútbol, de un país o de una religión. No poseemos los objetos, son ellos los que nos poseen.

Y hablando de religión, no creo que haya habido nunca ninguna otra institución que haya sabido emplear mejor el poder de las imágenes que la religión católica. Todo un programa de imágenes conmovedoras, patéticas, sublimes, grandiosas, fantásticas, trágicas, resplandecientes, apocalípticas, bellas, para conseguir todo tipo de reacciones emocionales: recogimiento, temor, piedad, ilusión, amor. Pero también, un programa de comportamientos ritualizados, arrodillarse ante las imágenes, santiguarse, dar limosna o comprar bulas. El anunciante no espera tanto, no persigue que sus consumidores se arrodillen ante su producto, pero sí que se inclinen ante su poder soberbio de seducción, que lo compren, que hablen de él, que ocupe sus pensamientos.

Tan sólo aquellas marcas que superan los límites del mercado, aquellos productos que consiguen ser algo más que mercancías, para pasar a formar parte del tejido social, del entramado cultural, conseguirán sobrevivir en un escenario de crisis de todos los valores, de descrédito de todas las instituciones y de feroz competencia a un nivel global.

Sólo eso puede explicar las peregrinaciones de los consumidores ante el "advenimiento" de un nuevo gadget de Apple, las colas ante los distribuidores para conseguir el último juego para consola de PlayStation, la mirada embobada ante los escaparates de Mercedes Benz. 


\subsection{Los rituales del consumo}

Tan sólo unos apuntes sobre los rituales vinculados a la publicidad.

De tiempo es sabida la relación entre el mito y los rituales que suelen acompañarle. En el caso de la mitificación de las marcas, ese ritual, necesario en el origen y conformación de un mito, dispone de varios escenarios básicos: los espacios de consumo, las actividades promocionales (salones, ferias, exposiciones) y los propios anuncios que recrean un "espacio mítico" mediante la presentación ritualizada de los productos.

El anuncio de la Fig. 7 contiene una de estas escenografías rituales: el altar en la forma de un gran número cinco, la figura flotante de una modelo que, a modo de gran sacerdotisa, avanza hacia el espectador y nos ofrece la comunión con el producto. 


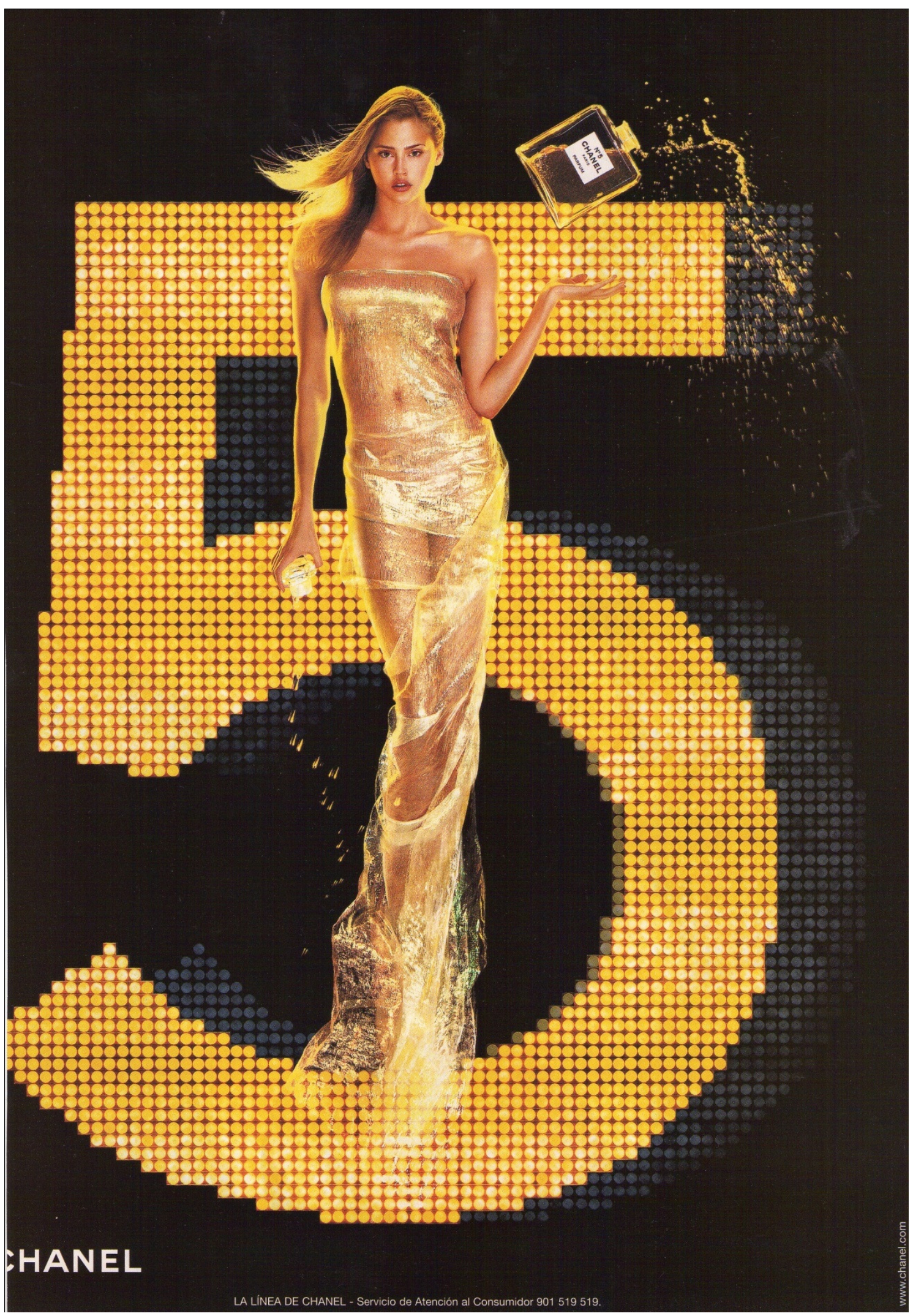

Fig. 7. Chanel № 5, c. 2000

REDMARKA UIMA-Universidad de A Coruña - CIECID

Año V, Número 9, (2012), v1 pp. 91-129

http://www.redmarka.org/

ISSN $1852-2300$ 
Ahí están, el esplendor y la suntuosidad propios de las ceremonias, la luminiscencia sobrenatural que parece emanar de las figuras. Todo parece dispuesto para introducir al espectador en ese espacio irreal, impresionante, bombástico, en el que sus defensas intelectuales sean anuladas por la presencia sublime de la mercancía.

Luego están los rituales de iniciación, en los que se transmite generacionalmente o transversalmente las costumbres consumidoras, en el entorno "mágico-religioso" de las grandes superficies, los supermercados, los centros de ocio.

El centro comercial adopta la forma de una pequeña ciudad desde fuera, pero casi infinita en su interior. Un lugar sin límites, ni leyes -excepto las del comercio, claro- donde no es de día ni de noche, no es verano ni invierno, no hay arriba ni abajo. El consumidor se sumerge en un dédalo de escaleras, pasillos y vestíbulos, luces brillantes y musiquillas idiotas. Sus sentidos se extravían y sufre una "borrachera" que lo deja completamente inerme ante los estragos del consumo.

\footnotetext{
Ese lugar cálido, tibio, reposado, donde no corre el tiempo, sin conflictos, lugar de la perfecta holganza, donde el consumidor se siente protegido, a salvo de los problemas del trabajo o del paro, de la familia o de la soledad, lejos del tráfico, de la contaminación; ese lugar es el seno materno, el vientre del capitalismo. El útero es la meta, el final, la culminación. El proceso de infantilización de la sociedad parece imparable, el proceso disneyzación al estilo americano parece inevitable. Para entrar en el cielo del capitalismo tenemos que ser como niños. La infancia es el paraíso. La felicidad de las damas se ha convertido en el jardín de infancia de todos (hombres y mujeres). Al fin y al cabo nunca fuimos más felices que cuando niños. (Eguizábal, R. 2007: 263)
}

Para extraviar los sentidos, para perderse, para olvidar, para el desorden, para el exceso, para gozar, para alborotar, para regresar a la infancia, cada cultura disponía de su droga. Freud (1980: 112) hablaba del "valioso servicio que el 
alcohol rinde al hombre" transformando su estado de ánimo, debilitando las fuerzas coercitivas y siendo en consecuencia una fuente de placer. El precio era alto, se pagaba con la salud, con la juventud, con la cordura. Ahora disponemos del centro comercial. El precio no es menos alto, se paga con la angustia de si llegaré a fin de mes, con la incertidumbre de la hipoteca, con la agonía de los pagos aplazados.

Pero donde posiblemente el aspecto ritual alcanza su dimensión más sobresaliente es en la escenografía de las actividades promocionales (salones, ferias). Existe todo tipo de acontecimiento de esta clase vinculada a todo tipo de mercancías y actividades comerciales, salones de la vivienda, ferias del calzado, de arte, salones del cómic o del disco, de la electrónica o la informática... Pero, puesto que el automóvil ha sido el objeto de culto por excelencia, es lógico que sus rituales sean así mismo paradigmáticos:

\begin{abstract}
“(...) basta con visitar el salón anual del automóvil para reconocer una manifestación religiosa profundamente ritualizada. Los colores, las luces, la música, la reverencia de los adoradores, la presencia de las sacerdotisas del templo (las maniquíes), la pompa y el lujo, el derroche, la masa compacta -todo esto constituiría en otra civilización un oficio auténticamente litúrgico- El culto del automóvil sagrado tiene sus fieles y sus iniciados. El gnóstico no esperaba con más impaciencia la revelación oracular que el adorador del automóvil los primeros rumores sobre los nuevos modelos. Es en ese momento del ciclo periódico anual cuando los pontífices del culto -los vendedores de automóviles- cobran una importancia nueva, al mismo tiempo que una multitud ansiosa espera impacientemente el advenimiento de una nueva forma de salvación" (A. Greeley en Eliade: 1973: 205)
\end{abstract}

En un espacio magnificente se concentran fabricantes y vendedores, se crea una especial predisposición, "un clima", como es propio de los rituales. Un clima favorecedor de la adoración y el entusiasmo ante los objetos de culto, y favorecedor de las transacciones comerciales; pues, a la postre, de eso se trata. 
Al automóvil, como objeto preciado, sublimador de todo de tipo de aspiraciones secretas, deseos inconfesados y complejos mal llevados, se le han unido nuevos gadgets, tablets, teléfonos móviles, ipods, que arrastran multitudes, pueblan sueños y ensoñaciones, crean adicciones furibundas y entusiasmos desmedidos.

\section{CONCLUSIONES}

Los mitos siguen vivos, pues, y no solamente en las sociedades ágrafas 0 primitivas, también en nuestro entorno contemporáneo, tecnológico y atravesado por conexiones múltiples. Perviven en la nostalgia de una "perfección primordial" que se advierte en los anuncios de cosmética; en la obsesión por el éxito social o económico que preside tanto nuestras vidas como los anuncios de colonia o de automóviles; en la cascada de emociones afectivas que movilizan las grandes marcas (Apple, Nike, Microsoft, Chanel, etc.); en las fantasías de superación, de excepcionalidad; en las luchas entre el Bien y el Mal encarnados por fuerzas de consumo; en la transformación de ciertas personas en imágenes ejemplares que realizan muchas veces los medios de comunicación. No podemos sino estar de acuerdo con Barthes cuando afirma que "sigue abundando lo mítico en nuestra sociedad: igualmente anónimo, retorcido, parlanchín, fragmentado" (Barthes: 1987: 84), y ello aún considerando el tiempo transcurrido desde que el pensador francés escribiese estas líneas.

Lo que ocurre es que esta nueva mitología responde a otros intereses. No hay en ella nada sagrado ni trascendente. Tiene que ver con el consumo, con el mercado, con las más pedestres aspiraciones del ser humano actual. El esfuerzo de los medios de comunicación a la hora de mitificar a actores, deportistas, presentadores, es rentabilizado comercialmente en los anuncios en los que esos mismos personajes aparecen de forma recurrente.

La publicidad demuestra, en definitiva, que en una sociedad tecnológica, materialista y aparentemente racional, sobrevive una serie de mecanismos míticos, de creencias y de formas de fe, que ahora son depositadas en marcas 
y en mercancías. Los grandes discursos, el Arte, la Religión, no han desaparecido, tan sólo han desplazado sus zonas de interés. Ni han desaparecido los templos, que ahora resurgen transustanciados en Grandes Superficies, Centros de Ocio, Parques Temáticos y otras "maravillas" de nuestro tiempo. Las presentaciones de Steve Jobs, como nuevo profeta de la era tecnológica, con una puesta en escena perfectamente estudiada, eran el mejor ejemplo de una sociedad cabalmente ritualizada. Incluso su muerte prematura parece ahora tan en concordancia con los esquemas propios del héroe o del profeta, y no digamos su infancia, abandonado por sus padres biológicos y adoptado por una nueva familia, como Moisés y como Supermán.

Apple, en este sentido, es el ejemplo perfecto de lo que puede conseguirse empleando mecanismos de mitificación. Su origen, en un garaje californiano, bajo la mirada atenta de sus padres intelectuales -un par de modestos estudiantes, un tanto hippies- tiene esa misma atmósfera oscura y modesta del origen de los héroes o de los mesías. El icono de la manzana mordida, el fruto del bien y del mal, recurre a un emblema de una larga tradición judeocristiana y de gran riqueza simbólica. No era nada original (los Beatles, sin ir más lejos, habían utilizado ese mismo emblema para su casa de discos y productora), pero ello nos demuestra también que no siempre las ideas más originales son las más acertadas.

Todo esto -resulta ostensible- apesta a religión. Apple no fue fabricado, "nació" en un trastero de California, como Jesucristo en un pesebre de Belén. Tuvo duros comienzos, hasta que por fin pudo oírse su voz clamando en la escena de los medios de comunicación. El famoso anuncio de Ridley Scott, basado en 1984 de Orwell, revivió así mismo esa lucha entre las fuerzas del mal (IBM Gran Hermano) y las del bien (Apple Macintosh) encarnadas, los tiempos mandan, en una elástica figura femenina; en una de las mejores y más impactantes películas publicitarias de todos los tiempos.

Por supuesto que ni el nacimiento de Apple, ni la muerte de Jobs fueron acontecimientos programados. La estrategia mitificadora consiste, más que en inventar, en saber utilizar ciertas contingencias para construir con ellas un relato mítico. 
Es obvio que el éxito de una empresa no puede relegarse al empleo de determinados recursos míticos, como tampoco es posible pensar que la publicidad sea capaz de levantar por sí sola una empresa, si no hay algo más detrás: un buen producto, recursos de comercialización, un cuidado diseño. Tampoco es que uno proyecte ciertos acontecimientos, como la forma y las circunstancias en que se crea un producto, o la biografía de su creador, sino que sepa aprovecharlas estratégicamente, sean cuales sean.

En todo caso, creo que queda explícito, que los viejos dispositivos de la mitificación siguen siendo una estrategia publicitaria válida en los tiempos de las nuevas tecnologías. En este sentido la llegada de Internet, (buscadores, redes sociales, chats, correos, etc.) no modifica en nada la estrategia, tan sólo pone en manos del anunciante o fabricante un mayor número de recursos a través de los cuales poner en práctica su programa para hacer de su marca $o$ producto un mito de nuestro tiempo.

\section{BIBLIOGRAFÍA}

Barthes, R. (1980) Mitologías. Madrid. Siglo XXI.

(1987) El susurro del lenguaje. Barcelona. Paidós Comunicación.

Dorfles, G. (1969) Nuevos ritos. Nuevos mitos. Barcelona. Lumen.

Eguizábal (2007) Teoría de la publicidad. Madrid. Cátedra.

(2009) Industrias de la conciencia. Barcelona. Península

Eliade, M. (1973) Mito y Realidad. Madrid. Guadarrama

(1976) "Los mitos y el pensamiento mítico" en Eliot, A. et alt. Mitos pp. 12-29.

Eliot, A. et alt. (1976) Mitos. Barcelona: Labor.

Freud, S. (1980) El chiste y su relación con el inconsciente. Madrid. Alianza

Harris, M. (1985) Vacas, cerdos, guerras y brujas. Los enigmas de la cultura. Madrid. Alianza.

Lévi-Strauss, C. (1987) Mito y significado. Madrid. Alianza.

Schultz, B. (2008) Correspondencia. Maldoror ediciones. 